\title{
Optimized Determination of Plasma Prokallikrein on a Hitachi 705 Analyser
}

\author{
By A. Adam, M. Azzouzi, J. Boulanger, P. Ers
}

Laboratoire de Biologie Clinique, C. H. de Sainte Ode, Baconfoy, Belgium

Laboratoire de Radioimmunologie (Prof. P. Franchimont), Université de Liege, Belgium

A. Albert

Laboratoire de Chimie Médicale (Prof. C. Heusghem), Université de Liege, Belgium

\section{J. Damas}

Institut de Physiologie normale et pathologique (Prof. J. Lecomte), Université de Liege, Belgium and

M. E. Faymonville

Service d'Anesthésiologie (Prof. M. Lamy), Université de Liege, Belgium

(Received July 19/October 22, 1984))

Summary: Manual determination of plasma prokallikrein using a chromogenic substrate is tedious. We describe the optimal conditions of enzymatic quantification by a fully automated method enabling rapid availability of the results and an easier estimation of this interesting compound in clinical chemistry.

\section{Optimierte Bestimmung von Prokallikrein im Plasma mit dem Hitachi 705 Analyser}

Zusammenfassung: Die manuelle Bestimmung von Prokallikrein im Plasma mit einem chromogenen Substrat ist anspruchsvoll. Wir beschreiben die optimalen Bedingungen für die enzymatische Bestimmung als Kallikrein mit einer vollautomatisierten Methode, deren Ergebnisse kurzfristig erhalten werden können und die diesen interessañnten Bestañdteil des Plasmas einer einfacheren Bestimmung zugänglich macht.

\section{Introduction}

Hageman factor (factor XII) is activated by contact with negatively charged surfaces (e.g. dextran sulphate, ellagic acid). The cleavage products of factor XII activate plasma prokallikrein to plasma kallikrein. The latter will liberate preferentially bradykinin from high molecular weight kininogen. The availability of chromogenic and fluorogenic substrates (1) has made possible the study of the physiopathological significance of this protease.
However, this quantification requires a prior "in vitro" activation. This two step procedure and the rapid inactivation of plasma prokallikrein by antiproteases make difficult the application of this manual procedure in routine clinical and chemical analysis. Here, we describe a fully automated method for the quantification of human plasma prokallikrein. After analytical validation and reference value determinations, we first applied this method to the study of patients undergoing aortocoronary bypass grafts under nonpulsatil cardiopulmonary bypass. 


\section{Material and Methods}

Blood sampling

After elimination of the first milliliter to remove "endogenous" tissue activator, blood is collected by venipuncture in 0.1 mol/l sodium citrate as anticoagulant (one part sodium citrate to nine parts blood) in a polystyrene tube. The sample is centrifuged $\left(15^{\circ} \mathrm{C}, 10 \mathrm{~min}, 1500 \mathrm{~g}\right)$ within $1 \mathrm{~h}$ after collection. The supernatant is removed with a plastic pipette. The plasma can be stored at $-30^{\circ} \mathrm{C}$ and plasma prokallikrein determined within one month.

\section{Reagents}

The chromogenic substrate used to quantify plasma prokallikrein activated to kallikrein is chromozym PK (Bz-ProPhe-Arg-pNA $\cdot \mathrm{HCl}$ ), $M_{\mathrm{r}}=679.3$ (Boehringer Pharma, Mannheim, FRG).

The incubation buffer is Imidazole/Tris $0.33 \mathrm{~mol} / 1 \mathrm{pH} \mathrm{7.9,}$ containing $\mathrm{NaCl} 0.33 \mathrm{~mol} / \mathrm{l}$. Various activators have been tested: dextran sulphate $\left(M_{\mathrm{r}}=500000\right.$, Pharmacia, Upsala, Sweden), dextran sulphate plus acetone or acetonitrile (analysis grade, Merck, Darmstadt, FRG), cephotest (Nyegaard, Oslo, Norway), thrombofax (Ortho Diagnostic System, New Jersey, USA).

\section{Instruments}

A model 24 spectrophotometer (Beckman Instruments, Brea, USA) was used for the manual determination of plasma prokallikrein. Fully automatic measurements were made with a Hitachi 705 system (Naka works, Katsuba, Japan).

\section{Procedure}

The manual determination of plasma prokallikrein was performed according to the original technique described by Kluft (2). However, aqueous solutions of dextran sulphate $(25 \mathrm{mg} / \mathrm{l})$ containing increasing concentrations of acetone or acetonitrile $(0,100,200,300,400 \mathrm{ml} / \mathrm{l})$ were tested as activator at four different temperatures $\left(4,15,26\right.$ and $\left.37^{\circ} \mathrm{C}\right)$. After adding $25 \mu \mathrm{l}$ of the activator to $25 \mu \mathrm{l}$ of plasma, the sample was incubated for various time intervals ranging from 150 to $900 \mathrm{~s}$. Measurement was made at $405 \mathrm{~nm}\left(37^{\circ} \mathrm{C}\right)$ over $3 \mathrm{~min}$.

For the automatic determination, activation and measurement of the resulting kallikrein catalytic activity was performed at the same temperature. We tested three kinds of activator diluted in the incubation buffer: dextran sulphate (initial concentration: 10. $25,50 \mathrm{mg} / \mathrm{l}$ ), cephotest and thrombofax (initial dilution $100,75$ and $50 \mathrm{ml} / \mathrm{l})$.

Plasma $(5 \mu \mathrm{l})$ was incubated with the activation mixture $(500 \mu l)$. Then the automatic systems adds $60 \mu \mathrm{l}$ of the substrate (initial concentrations of $4 \mathrm{mmol} / \mathrm{l}$ ). The incubation times $(6 \min 20 \mathrm{~s}, 7 \mathrm{~min} 20 \mathrm{~s}$, or $8 \min 20 \mathrm{~s})$ were determined by the instrumental conditions. Afterwards the kallikrein catalytic activity is measured by the change in absorbance per minute $(\Delta \mathrm{A} / \mathrm{min})$ at $415 \mathrm{~nm}$.

The results were calculated by multiplying the $\Delta \mathrm{A} / \mathrm{min}$ value by 10.865 . This factor was obtained as follows:

$$
\begin{aligned}
\text { Catalytic concentration }(\mathrm{U} / \mathrm{l}) & =\frac{\Delta \mathrm{A}}{\min } \times \frac{0.565 \times 100}{1040 \times 0.005} \\
& =\frac{\Delta \mathrm{A}}{\min } \times 10.865
\end{aligned}
$$

0.565 is the final volume, 0.005 the sample volume and 1040 the molar lineic absorbance of p-nitroaniline.
The effect of heparin $(0-10 \mathrm{U} / \mathrm{ml})$. (Calparin Roche, Basel, Switzerland) and its antagonists (protamine sulphate, Roche; polybrene, Aldrich Europe, Beerse, Belgium) on plasma prokallikrein measurement were tested using a plasma pool. Because $1 \mathrm{mg}$ of polybrene or $1 \mu \mathrm{l}$ of protamine sulphate neutralizes 1000 units of heparin, the concentrations of protein and coagulation factors were the same in each sample.

For this study and for the samples 'containing heparin, this anticoagulant was first quantified by a thrombin time test using titrarine (Stago, Asnières, France) or with a chromogenic substrate assay (Boehringer Pharma, Mannheim, GFR).

\section{Reference values and clinical application}

To determine the reference range, plasma specimens from 87 healthy adults were assayed. These subjects $(20-35$ years) had neither symptoms of inflammation nor hepatic insufficiency. The influence of oral contraceptive $(n=46)$ and pregnancy $(n=193)$ on plasma prokallikrein values was also tested.

The method was checked on patients $(n=5)$ undergoing cardiac surgery. To exclude biochemical changes due to surgery, we did the same tests on patients undergoing total hip replacement. Blood samples were collected from radial artery and internal jugular vein; the various results were corrected for haemodilution and were compared with the initial value by a Student t test.

\section{Results}

\section{Effect of various activation conditions}

A comparative examination of figure 1 shows that highest values are obtained after an activation time of at least $7 \mathrm{~min} 30 \mathrm{~s}$ at $4{ }^{\circ} \mathrm{C}$ with dextran sulphate alone or in the presence of acetone (volume fraction 0.1 ). When higher concentrations of acetone are used, the values are clearly lower.

When the activation temperature is increased to 15 , 26 , and finally $37^{\circ} \mathrm{C}$, the maximum value obtained with dextran sulphate alone or in the presence of acetone (volume fraction $\mathbf{0 . 1}$ ) is lower and decreases progressively with the time of activation. However, at these temperatures the values obtained with a volume fraction of 0.20 acetone are more stable during incubation. In any case, the results were similar for acetonitrile. The lowest values were found after activation with a volume fraction of 0.40 acetone, due to protein precipitation.

\section{Automated method}

\section{Selection of optimal assay conditions and analytical characteristics}

The values obtained at 25 and $37^{\circ} \mathrm{C}$ with the three activators are shown in figure 2. At $30^{\circ} \mathrm{C}$ intermediate values were obtained (results not shown). 


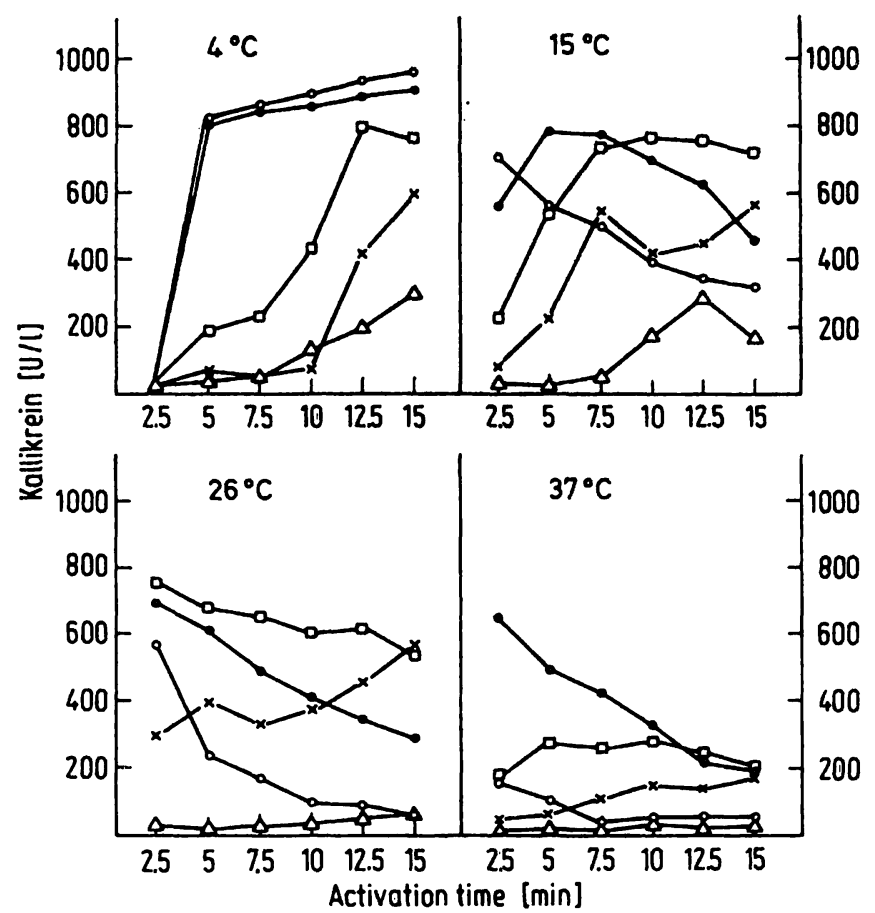

Fig. 1. Kinetics of plasma prokallikrein activation at four temperatures using the manual method.

Activators:

dextran sulphate alone (-O-);

dextran sulphate plus acetone, volume fraction

$0.1(-\boldsymbol{O}-), \quad 0.2(-\square-), \quad 0.3(-\mathrm{x}-), \quad 0.4(-\Delta-)$

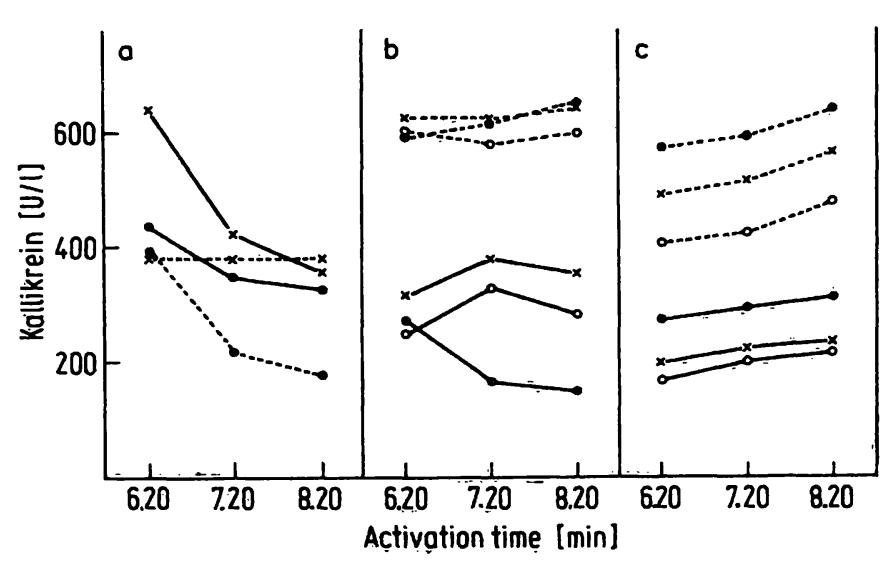

Fig. 2. Selection of optimal conditions for plasma prokallikrein activation on the Hitachi 705 using two different temperatures, $25^{\circ} \mathrm{C}$ (full lines) and $37^{\circ} \mathrm{C}$ (dashed lines).

a) dextran sulphate: $25 \mathrm{mg} / \mathrm{l}(-\mathrm{x}-) ; 10 \mathrm{mg} / \mathrm{l}(-0-)$

b) cephotest $75 \mathrm{ml} / 1(-\mathrm{x}-) ; 100 \mathrm{ml} / \mathrm{l}(-\odot-) ; 50 \mathrm{ml} / 1$ (-O-)

c) thrombofax $75 \mathrm{ml} / 1(-\dot{\mathrm{x}}-) ; 100 \mathrm{ml} / 1(-\odot-) ; 50 \mathrm{ml} / \mathrm{l}$ (-O-)

Using dextran sulphate, the catalytic activities decreased with the time of activation. At $50 \mathrm{mg} / \mathrm{l}$, no catalytic activity was obtained, due to protein precipitation.

With thrombofax or cephotest, the catalytic activity after $6 \mathrm{~min} 20 \mathrm{~s}$ increased with temperature. At $37^{\circ} \mathrm{C}$, the catalytic activity obtained with cephotest increased with the time of activation - the maximum being reached after $8 \mathrm{~min} 20 \mathrm{~s}$, using a volume fraction 0.1 of this activator in the buffer. The following optimal conditions were selected for the continuation of this study: $5 \mu \mathrm{l}$ of plasma activated by incubation for $8 \mathrm{~min} 20 \mathrm{~s}$ at $37^{\circ} \mathrm{C}$ with $500 \mu \mathrm{l}$ of cephotest $1 / 10$ diluted in the incubation buffer.

The analytical characteristics are shown in table 1. The within-run precision as well as the precision within and between days, are excellent. The coefficient of variation is in each case less than $5 \%$. Using serial dilutions of plasma with a plasma prokallikrein value of $1000 \mathrm{U} / 1$ a linear relation was obtained up to $5 \mathrm{U} / \mathrm{l}$. This level was chosen as the limit of sensitivity of our automated method.

Tab. 1. Plasma prokallikrein assay: Precision obtained with the fully automated method.

Within run precision $(\mathrm{n}=20)$

\begin{tabular}{lll} 
Mean & $\mathrm{SD}$ & $\mathrm{CV}$ \\
$(\mathrm{U} / \mathrm{l})$ & $(\mathrm{U} / \mathrm{l})$ & $(\%)$ \\
872 & 9 & 1.03 \\
448 & 3 & 0.66 \\
176 & 5 & 2.84 \\
Run-to-run precision $(\mathrm{n}=5)$ & & \\
Mean & $\mathrm{SD}$ & $\mathrm{CV}$ \\
$(\mathrm{U} / \mathrm{l})$ & $(\mathrm{U} / \mathrm{l})$ & $(\%)$ \\
686 & 10 & 1.46 \\
Day-to-day precision $(\mathrm{n}=25)$ & \\
Mean & & \\
$(\mathrm{U} / \mathrm{l})$ & $\mathrm{SD}$ & $\mathrm{CV}$ \\
698 & $(\mathrm{U} / \mathrm{l})$ & $(\%)$ \\
& & \\
\hline
\end{tabular}

The results obtained with this automated method show an excellent correlation $(r=0.96)$ with those obtained using the manual reference method (fig. 3).

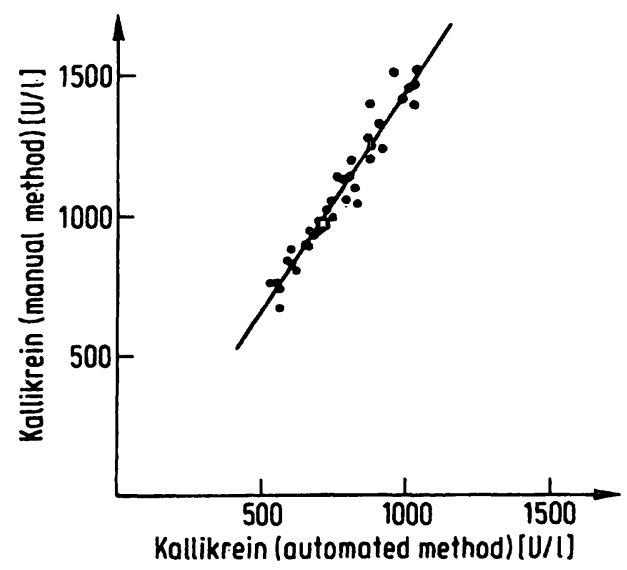

Fig. 3. Correlation between plasma prokallikrein measured as kallikrein catalytic activities obtained with manual and automated method. $y=-13.79+1.59 x(n=40)$. 
Figure 4 represents the levels of plasma prokallikrein when increasing quantities of heparin $(0.5-10 \mathrm{U} / \mathrm{ml})$ were added to a pool plasma. The plasma prokallikrein values decrease progressively up to $4 \mathrm{U} / \mathrm{ml}$ heparin. A plateau equal to one third of the initial value is then observed between 4 and $10 \mathrm{U} / \mathrm{ml}$.

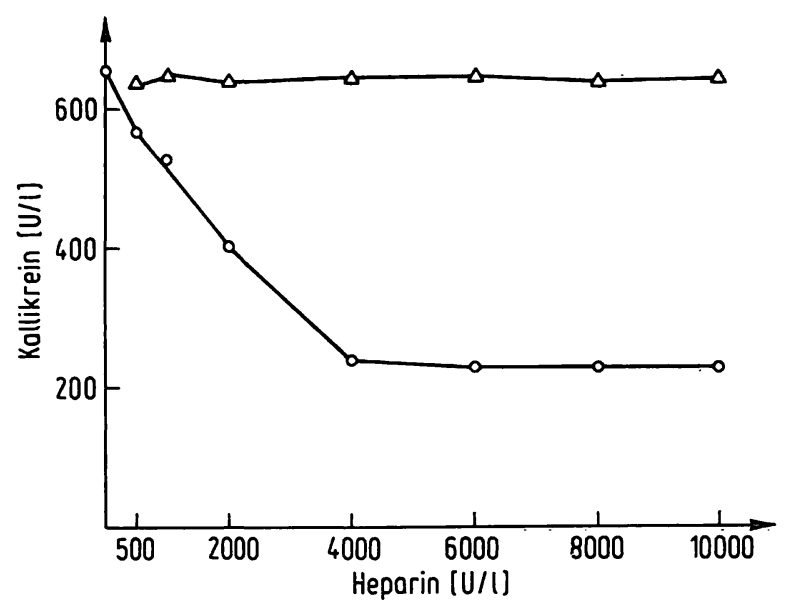

Fig. 4. Effect of increasing levels of heparin $(\mathrm{U} / \mathrm{l})$ before $\left(-\mathrm{O}^{-}\right)$ and after neutralization $(-\Delta-)$ with polybrene or protamine sulphate on plasma prokallikrein measured as kallikrein catalytic activities (U/l).

When equivalent quantities of polybrene or protamine sulphate are added to neutralize the heparin, the initial value is preserved. An excess of both substances equivalent to $5 \mathrm{U} / \mathrm{ml}$ of heparin does not interfere in the quantification of plasma prokallikrein.

\section{Reference values}

The distribution of the results for healthy adults is shown in table 2. There is no significant difference between plasma prokallikrein values for men and women. However, women taking oral contraceptives and pregnant women have significantly higher plasma prokallikrein.

Tab. 2. Reference values of plasma prokallikrein (U/l).

\begin{tabular}{lllll}
\hline Group & $\mathrm{N}$ & Mean \pm 1 SD & $\begin{array}{l}\text { Group } \\
\text { comparison } \\
\mathrm{t}\end{array}$ & \\
\hline 1 men & 35 & $732 \pm 108$ & 1 vs 2 & 1.55 \\
2 women & 52 & $695 \pm 112$ & 2 vs 3 & $7.31^{*}$ \\
$\begin{array}{l}3 \text { women using } \\
\text { oral contra- } \\
\text { ceptives }\end{array}$ & 46 & $893 \pm 155$ & 3 vs 4 & 1.18 \\
$4 \begin{array}{llll}\text { pregnant } \\
\text { women }\end{array}$ & 193 & $861 \pm 167$ & 4 vs 2 & $6.76^{*}$ \\
\hline
\end{tabular}

* significant $\mathrm{p}<0.001$
Application of the plasma prokallikrein determination in surgery

Patients undergoing cardiac surgery receive large doses of heparin. The levels of this anticoagulant in plasma determined by a thrombin time test varies between 0.5 and $5 \mathrm{U} / \mathrm{ml}$. Quantification of plasma prokallikrein has been achieved with and without in vitro-neutralization of heparin by adding equal amounts of protamine sulphate. The results are shown in figure 5.

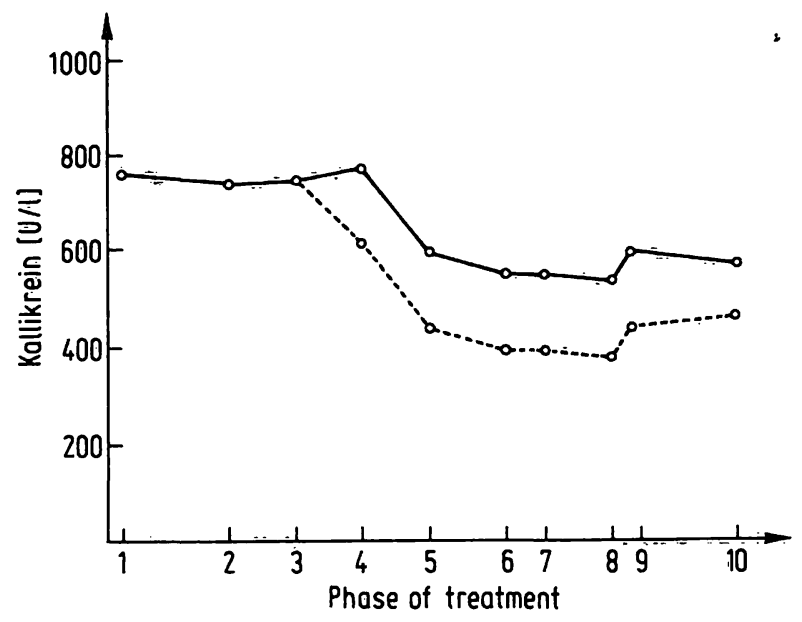

Fig. 5. Variation of plasma prokallikrein measured as kallikrein catalytic activity (U/l) during cardiac surgery before $(--)$ and after $(-)$ neutralisation of heparin. 1: presurgery, 2: anesthesia, 3: surgery, 4-8: cardiopulmonary bypass, 9: 15 minutes after cardiopulmonary bypass, 10 : intensive care unit.

No significant difference is obŝ̀erved between arterial and venous prokallikrein plasma levels. After start of anesthesia and after sternotomy, plasma prokallikrein shows no significant changes. At the beginning of cardiopulmonary bypass, a significant drop ( $p<0.05)$ in plasma prokallikrein can be observed. This decreased plasma prokallikrein lasts until the lungs are reperfused. Although the variations are more important without neutralization of heparin, the differences are significant in both cases. During total hip replacement no statistical variation of plasma prokallikrein was observed at any time during surgery.

\section{Discussion}

Chromogenic and fluorogenic substrates are now commercially available (1) for enzymatic quàntification of plasma prokallikrein. We used chromozym PK. The results obtained with the chromogenic sub: strate S-2302 (Kabi, Diagnostica, Stokholm, Sweden) are comparable (3). 
This enzymatic determination necessitates a prior activation of Hageman factor by contact with negatively charged sufaces. Various activators have been described: dextran sulphate (2), ellagic acid (4) and a preparation of high molecular weight kininogen and Hageman factor (Kabi, S-11287).

The activated plasma kallikrein is bound to antiproteases such as: C1 esterase inhibitor, antithrombin III, $\alpha_{1}$-proteinase inhibitor. Various approaches have been tried to diminish this interaction during activation of plasma prokallikrein at low temperature (1), e.g. dilution of the incubation medium (4), addition of a hydrophilic organic solvent (3) or exposure of the plasma to a hydrophobic solvent (5).

With the manual determination, maximal catalytic activities are obtained at $4{ }^{\circ} \mathrm{C}$ with dextran sulphate alone or dextran sulphate plus acetone or acetonitrile (volume fraction 0.1 ). When measurements are performed at higher temperatures, acetone seems to have a protective effect on the resulting kallikrein; its inhibition by various antiproteases seems to be temperature dependent. The effect of these inhibitory proteins is more pronounced at 25 and $37^{\circ} \mathrm{C}$. At these temperatures, acetone has in fact two effects early inhibition of activation, and later protection of kallikrein catalytic activity.

When adapting this determination to a Hitachi 705 , plasma prokallikrein must be activated and quantified at the same temperature. Under these optimized conditions, the use of ellagic acid as the activator leads to results that are perfectly correlated with those obtained by the reference method of Kluft (2). The fully automated method therefore gives a reliable measurement of plasma prokallikrein levels.
Like others, we observed that heparin lowers plasma prokallikrein values, but heparin can be neutralized before activation is started. This will be useful for application of the assay to patients with acute inflammatory disease who often receive heparin. Like Ito \& Statland (3), we noted no difference between sexes. However, pregnant women and women taking oral contraceptives had significantly higher plasma prokallikrein values. In these two cases, the increased plasma prokallikrein must be due to an increase in hepatic synthesis. The extracorporeal circulation study shows a negative influence of heparin on kallikrein catalytic activity, but also an activation of plasma prokallikrein during cardiopulmonary bypass. This activation of plasma prokallikrein is probably not due to surgery, as can be concluded from the results obtained in orthopedic surgery, but probably to the contact of the blood with negatively charged surfaces $(6-8)$.

In conclusion, we have described a reliable fully automated determination of plasma prokallikrein, which will facilitate further exploration of the kallikrein-kininogen-kinin system in various pathophysiological conditions (9). The application of this method to routine clinical chemical analysis is also described.

\section{Acknowledgement}

We are very gratefull to Dr $S$. Hess (Boehringer, Mannheim) for critical review of this manuscript.

We particularly appreciated the precious assistance of Mrs. Duplicy-Genin in dactylography of this paper. This work has been granted by the F.R.S.M. 3.4529.81.

\section{References}

1. Fareed, J., Messmore, H. L.., Walenga, J. M. \& Bermes, E. W. (1983) CRC Critical Reviews in Clinical Laboratory Sciences 19, 70-134.

2. Kluft, C. (1978) J. Lab. Clin. Med. 91, 83-95.

3. Ito, R. \& Statland, B. E. (1981) Clin. Chem. 27, 586- 593.

4. Gallimore, M. J., Amundsen, E., Larsbaarten, M., Lyngaas, K. \& Faried, E. (1979) Thrombosis Research 16, 695-703.

5. Fisher, C. A., Schmaier, A. H., Addonizio, V. P. \& Colman, R. W. (1982) Blood 59, 963-970.

6. Seidel, G., Meyer-Burgdorff, C. \& Habel, E. (1972) Experientia 28, 1193-1199.

7. Wiegershausen, B., Hennighausen, G. \& Lange, G. (1970) Experientia 26, 118-119.

8. Oh Ishi, S. \& Webster, M. E. (1975) Pharmacology 24, $591-598$.

9. Deutsch, E., Dragosics, B., Kopsa, H., Mannhalter, Ch. \& Rainer, H. (1983) Thrombosis Research 31, 351-364. 
